\author{
ks. Wojciech Zyzak ${ }^{1}$ \\ 0000-0002-7756-1303
}

Uniwersytet Papieski Jana Pawła II w Krakowie

\title{
Holistyczny charakter duchowości chrześcijańskiej
}

Niektórzy specjaliści zajmujący się tematem zdrowia ludzkiego podkreślają, że jego współczesne ujęcie wymaga wieloaspektowego rozumienia człowieka, uwzględniającego poziom nie tylko fizjologiczny, psychologiczny i społeczny, ale także duchowy². Takie ujęcie stawia wymaganie rozwijania właściwej antropologii, opisującej człowieka z perspektywy różnych nauk, także z punktu widzenia teologii³. Tym tendencjom wychodzi naprzeciw dążenie samej teologii, która - choćby w ujęciu Karla Rahnera - staje się coraz bardziej antropologią trans-

1 Ks. prof. dr hab. Wojciech Zyzak, ur. 1969 w Żywcu. Od 1993 kapłan diecezji bielsko-żywieckiej. Od 2014 rektor Uniwersytetu Papieskiego Jana Pawła II w Krakowie. Zainteresowania naukowe: duchowość laikatu, duchowość kapłańska, mistyka karmelitańska, duchowość zmartwychwstańców. Najważniejsze publikacje: Zjednoczenie z Bogiem w życiu Ojca Pio (Francesco Forgione). Studium na podstawie jego pism, Kraków 2000; Fundamentalna rola wiary w życiu i pismach świętej Teresy Benedykty od Krzyża (Edyty Stein), Kraków 2005; Co mam czynić, aby osiagnąć życie wieczne? Duchowość chrześcijańska na świeckiej drodze życia, Kraków 2008; Kapłaństwo prezbiterów. Studium nauczania Jana Pawła II, Kraków 2010. E-mail: wojciech. zyzak@upjp2.edu.pl.

2 Por. H. Wrona-Polańska, Twórcze zmaganie się ze stresem szansą na zdrowie, Kraków 2011, s. 92 .

3 Por. J. Orzeszyna, Zagrożenia antropologicznych podstaw rodziny na kanwie wypowiedzi Jana Pawła II, „Polonia Sacra” 12 (2008) 23, s. 107n. 
cendentalną. Orientacja antropocentryczna sprawia, że mające wpływ na teologię ujęcie człowieka staje się coraz bardziej ważkim zagadnieniem dla samej teologii ${ }^{4}$. Wspomniana współzależność jest najbardziej widoczna $\mathrm{w}$ badaniach duchowości, rozumianej jako doświadczenie duchowe. Ostatnie dziesięciolecia, zwłaszcza pod wpływem współczesnych ruchów w Kościele, pokazują tendencję w duchowości, by w integralnej wizji człowieka przezwyciężać tradycyjne dualizmy ducha i materii, duszy i ciała czy doczesności i wieczności ${ }^{5}$. Duchowość holistyczna unika wspomnianych dualizmów. Platońska dewaluacja świata zmysłów, Kartezjańska dychotomia materii i ducha oraz manichejska pogarda dla materii wiązanej z grzechem oddzieliły rzeczywistości, które zdaniem duchowości holistycznej winny być zjednoczone. Poniższe refleksje na temat duchowości holistycznej podkreślają integrującą, inkluzywną postawę komplementarności, która pragnie przezwyciężyć opozycje ducha i ciała, natury i łaski, sacrum i profanum oraz jednostki i społeczeństwa6.

\section{Integralna wizja osoby ludzkiej}

Przymiotnik „holistyczny” znajduje ostatnio zastosowanie na tak różnych polach jak medycyna, rozwój człowieka i duchowość. We wszystkich kontekstach główną troską jest „całościowość”, pragnienie integracji i próba zrozumienia powiązań pomiędzy różnymi aspektami rzeczywistości. Podobnie jak medycyna holistyczna, łącząca zdrowie fizyczne i psychiczne, holistyczna duchowość szanuje psychosomatyczną jedność osoby $^{7}$. Trzeba przyznać, że w historii duchowości nie zawsze tak było. U wielu autorytetów wpływ myśli greckiej, ujmującej ciało w ramach S. 318 .

4 Por. R. Winling, Teologia współczesna, przeł. K. Kisielewska-Sławińska, Kraków 1990,

5 Por. L. Gallo, Spiritualità dei movimenti di liberazione, w: Movimenti ecclesiali contemporanei, a cura di A. Favele, Roma 1980, s. 460.

6 Por. W. Au, Holistic Spirituality, w: The New Dictionary of Catholic Spirituality, ed. M. Downey, Collegeville 1993, s. 489.

7 Por. W. Au, Holistic Spirituality, dz. cyt., s. 488. 
metafizycznego dualizmu, prowadził do koncepcji heretyckich. Często cytowanym przykładem jest Ewagriusz z Pontu i jego teoria podwójnego stworzenia. W wyniku odejścia od Boga stworzeń duchowych Bóg miał stworzyć świat widzialny. W konsekwencji eschatologia Ewagriusza kończyła się kompletnym zniknięciem ciał. W jego ujęciu obecność człowieka w ciele jest więc wynikiem upadku ${ }^{8}$. Wpływ takich teorii sprawiał, że czasami chrześcijańską doskonałość utożsamiano z największym możliwym stopniem oddalenia się od materii, ciała i seksualności. Eschatologiczny akcent położony na bliskiej paruzji nie sprzyjał refleksji nad integralnym rozumieniem ludzkiego zdrowia i dobrostanu'.

Do pełnego obrazu integralnej wizji człowieka w duchowości należy jednak prawda o zwalczaniu przez Kościół od jego początków wszelkich form gardzącego materią manicheizmu, kwestionującego prawdę wcielenia Syna Bożego doketyzmu czy sprzecznego z chrześcijańską wizją życia duchowego enkratyzmu ${ }^{10}$. Właśnie prawda o wcieleniu stanowiła zawsze podstawę pozytywnego ujęcia duchowości inkarnacyjnej. Zasługą Dunsa Szkota jest myśl, że Logos stałby się człowiekiem, również gdyby nie doszło do grzechu pierworodnego, gdyż wcielenie należało do planu przebóstwienia ludzkości ${ }^{11}$. Duchowość franciszkańska podkreśliła wielkość człowieka, który został stworzony na obraz i podobieństwo Syna Bożego. Dla niektórych teologów również ciało ludzkie jest stworzone na obraz przyszłego Wcielonego Słowa ${ }^{12}$. To pozwala podkreślić integralną wizję człowieka, która zresztą jest wybitnie biblijna. W Piśmie Świętym zwrot „ciało i dusza” oznacza najpierw całego człowieka w jego relacji do Boga, siebie samego, innych ludzi i natury. Więc nie należy ich rozumieć komplementarnie czy wręcz biegunowo. Nie chodzi tu o dychotomię czy

8 Por. R. Bultot, Théologie des réalités terrestres et spiritualité du laïcat, „Revue Internationale de Théologie Concilium" 19 (1966), s. 39n.

9 Por. Y. M.-J. Congar, Jalons pour une théologie du laïcat, Paris 1954, s. 21n; Y. Congar, Laïc et Laïcat, w: Dictionnaire de spiritualité, t. 9, Paris 1976, k. 81n.

10 Por. A. Auer, Weltoffener Christ. Grundsätzliches und Geschichtliches zur Laienfrömmigkeit, Düsseldorf 1966, s. 25n.

11 Por. A. Auer, Weltoffener Christ..., dz. cyt., s. 123-127.

12 Por. K. Juzba, La compassione di Francesco d'Assisi per gli altri e per il Creato, „Polonia Sacra" 18 (2014) 1, s. 97. 
dualizm ${ }^{13}$. To fundamentalne podejście znajdujemy też w pozabiblijnej literaturze epoki. Ksiegga Henocha słowiańska należąca do apokaliptyki międzytestamentowej zawiera midraszycki opis stworzenia, który podkreśla więź człowieka z cała przyrodą. Jest to rozbudowany midrasz do tekstu starotestamentowego (Rdz 1, 26): „A szóstego dnia nakazałem swojej mądrości stworzyć człowieka z siedmiu składników: 1) jego ciało z ziemi; 2) jego krew z rosy i ze słońca; 3) jego oczy z niezgłębionego morza; 4) jego kości z kamienia; 5) jego rozum z żywości aniołów i z obłoków; 6) jego żyły i włosy z trawy ziemi; 7) jego ducha z mojego ducha i z wiatru". Warto podkreślić, że liczba 7 oznacza pełnię, doskonałość ${ }^{14}$.

Z powyższych refleksji teologicznych wynika, że ciało jest najbliższą i najcenniejszą, doświadczalną wartością ,ja" psychicznego. Nic nie jest tak bliskie mojemu ,ja" jak moje ciało. Jest ono elementem konstytutywnym osoby ludzkiej. Scholastyka określiła osobę bez ciała jako persona incompleta ${ }^{15}$. Gdy zabraknie tylko jakiejś części ciała, dusza nie może już wykonywać wszystkich swoich czynności, gdyż ciało ludzkie jest konieczną racją zaistnienia samej duszy, jej pośrednią przyczyną oraz czasoprzestrzennym kontinuum osoby ${ }^{16}$. Dlatego im lepiej rozwinięty jest organizm jako taki, tym doskonalszy stanowi fundament, wyraz i narzędzie duchowo-osobowej duszy człowieka. Stąd duchowe życie rozwija się bez problemu, gdy cielesny organizm funkcjonuje nienagannie. To stanowi jednak tylko negatywny warunek, czyniący duchowy rozwój możliwym. Pozytywnym warunkiem jest rozwój duszy duchowej. Powyższej zasady nie przekreśla fakt, że również zdrowe, dobrze wytrenowane i piękne ciało może być „,bez ducha”, a chore i słabe może być bardzo uduchowione ${ }^{17}$.Jak pisał Bernhard Häring: „Chrześcijańskie nastawienie

13 Por. R. Schulte, Leib und Seele. III. Systematisch-theologisch, w: Lexikon für Theologie und Kirche, t. 6, Freiburg im Breisgau 2006, k. 775n.

14 Por. S. Jędrzejewski, Pochodzenie człowieka w apokaliptyce międzytestamentalnej, „Polonia Sacra" 2 (1988) 46, s. 122.

15 Por. A. J. Nowak, Ślub czystości czy konsekracja ciała?, w: Ku szczęściu - bez oszustwa, pod red. J. Misiurka, A. J. Nowaka, W. Słomki, Lublin 1997, s. 160 (Homo Meditans, 18).

16 Por. P. Mrzygłód, Dusza i ciało jako integralne składowe ludzkiego bytu. Stanowisko metafizyki realistycznej, „Wrocławski Przegląd Teologiczny” 20 (2012) nr 1, s. 192.

17 Por. E. Stein, Der Aufbau der menschlichen Person. Vorlesung zur philosophischen Anthropologie, Freiburg im Breisgau 2004, s. 89. 
do ciała znalazło się w środku między spirytualistyczno-dualistycznym wrogim nastawieniem do ciała a materialistyczno-witalistycznym jego ubóstwieniem, między naiwnym optymizmem, który zapomina o grzechu pierworodnym, a czarnym pesymizmem, który w ciele ludzkim nie widzi śladów chwały Stwórcy i Odkupiciela"18.

Powyższa ewolucja w spojrzeniu na ciało człowieka miała również znaczenie dla kwestii tak istotnych w duchowości jak modlitwa. Tam, gdzie charakterystyczny rys ludzkiego istnienia był postrzegany jedynie $\mathrm{w}$ racjonalności, również modlitwa rozumiana była jako rozmyślanie ${ }^{19}$. Jednak list Orationis formas (26) kardynała Josepha Ratzingera z 1989 roku podkreślił, że pozycja i postawa ciała nie pozostają bez wpływu na stan ducha. Ciało jest ważnym elementem dialogu człowieka z Bogiem. Ważne są gesty modlitewne i przekonanie, że medytacja pomaga przeniknąć duchem ciało ${ }^{20}$. Właśnie niewerbalne rodzaje modlitwy pokazują wagę wyobraźni, zmysłów i uczuć na modlitwie w duchowości holistycznej ${ }^{21}$. We współczesnych centrach duchowych przyjmuje się nawet ciało jako punkt wyjścia w duchowości. Chodzi o ćwiczenia, by lepiej rozumieć język ciała. Wyciszenie pozwala wyrazić ciału, jakie siły poruszają człowiekiem. Ćwiczenia fizyczne i kontrola oddechu pomagają wyzwolić głębsze pokłady świadomości ciała i zidentyfikować zniekształcenia spontanicznego wyrazu, co ma wpływ na stan zdrowia człowieka ${ }^{22}$. Do głosu dochodzi tu nie tylko racjonalność, ale całe spektrum życia duchowego z wymiarem wolitywnym i emocjonalnym. Stąd tak często podkreślana w duchowości, choćby przez Dietricha von Hildebranda, rola serca, rozumianego jako centrum życia duchowego ${ }^{23}$.

\footnotetext{
18 B. Häring, Nauka Chrystusa, t. 3, Poznań 1963, s. 165.

19 Por. S. A. Ross, Body, w: The New Dictionary of Catholic Spirituality, dz. cyt., s. 93.

20 Por. P. Piasecki, Medytacja chrześcijańska. Antropologiczno-teologiczne podstawy w perspektywie duchowości azjatyckiej, Poznań 2008, s. 81n.

${ }_{21}$ Por. W. Au, Holistic Spirituality, dz. cyt., s. 488n.

22 Por. K. Waaijman, Handbuch der Spiritualität, t. 1, Mainz 2004, s. 35.

23 Por. S. T. Zarzycki SAC, Ku zrozumieniu istoty serca, w: Najważniejsza jest miłość, red. M. Chmielewski, Lublin 1999, s. 131n.
} 
Warto w tym kontekście wspomnieć o chrześcijańskiej mistyce, która stanowi szczyt spotkania z Bogiem, obejmującym całego człowie$\mathrm{ka}^{24}$. Mistyka jako pełnia miłości ma wybitnie integrujący charakter ${ }^{25}$. Wystarczy wspomnieć, że doświadczenia Mechtyldy z Magdeburga potwierdzają prawdę, że cały człowiek z duszą i ciałem zostaje włączony $\mathrm{w}$ relację z Synem Bożym, a przez to zyskuje przewagę nad aniołami. W tym doświadczeniu Boga ciało i zmysły nie przeszkadzają, ale są wręcz konieczne ${ }^{26}$. Nadzwyczajne doświadczenia, jak ekstaza i stygmaty, choć nie należą do istoty mistyki, rzutują na jakość relacji z Bogiem i całym stworzeniem. Nie jest przypadkiem, że zdrowy oryginał znalazł podróbkę w chorym poszukiwaniu chemicznych i niszczących zdrowie substancji o nazwie ecstasy. Dla wielu teologów popularność narkotyków jest między innymi znakiem niezaspokojonego głodu prawdziwej duchowości ${ }^{27}$. Jak wynika z powyższych rozważań, chrześcijańskie ujęcie duchowości opiera się na duchowo-cielesnej jedności człowieka i dlatego ma charakter holistyczny. W oparciu o teologię Karla Rahnera ks. prof. Marek Chmielewski stwierdził: „Duchowości i materialności ludzkiego bytu nie da się w żaden sposób rozdzielić, i to nie tylko w samej refleksji metafizyczno-antropolgicznej, ale także w płaszczyźnie praktycznej aktywności człowieka"28.

\section{2. Łaska budująca na naturze}

Wyżej opisane napięcie w postrzeganiu roli ciała w duchowości było konsekwencją różnego akcentowania elementów inkarnacji i eschatologii w teologii stworzenia i wcielenia oraz teologii odkupienia. Skutkiem

24 Por. M. Platting, „Die Gewalt der nackten Minne”. Gedanken zur weiblichen Mystik, w: Edith Stein Jahrbuch, t. 2, Das Weibliche, Würzburg 1996, s. 114-123.

25 Por. G. Moioli, Mistica cristiana, w: Nuovo Dizionario di Spiritualitá, a cura di S. De Fiores, T. Goffi, Roma 1979, s. 988.

26 Por. F. Beer, Kobiety i doświadczenie mistyczne w średniowieczu, przekł. A. Branny, Kraków 1996, s. 125-132.

${ }_{27}$ Por. J. W. Gogola OCD, Zjawiska towarzyszace mistyce: ekstaza i stygmaty, w: Stygmaty i stygmatycy, red. Z. Kijas, Kraków 2005, s. 47n.

${ }_{28}$ M. Chmielewski, Ciało i duchowość. Zarys problematyki, „Ethos” 4 (2008), s. 53. 
tego było nieco odmienne postrzeganie natury i łaski ${ }^{29}$. Czasami przeważała grecka koncepcja czasu, w której stawanie się oznaczało degradację, a czas wydawał się konsekwencją grzechu. Wszystko, co pozytywne w historii pochodziło wyłącznie z Bożej łaski. Dlatego zbawienie było postrzegane nie tyle jako wypełnienie, ile jako wyratowanie ze stworzenia, które stało się niebezpieczne ${ }^{30}$. Pewien rodzaj spirytyzmu, który nie chce, by chrześcijanin „skaził się" stworzeniem, w pewnym sensie neguje rzeczywistość wcielenia i popada $\mathrm{w}$ dualizm oddzielający stworzenie od zbawienia oraz naturę od łaski ${ }^{31}$.

Tymczasem Chrystus wymaga od uczniów, by byli dla świata zaczynem, światłem i solą (Mt 5,13n; 13,33). Wcielone Słowo jest objawieniem tego, czym człowiek naprawdę jest. Dlatego teologowie podkreślają ścisłą wewnętrzną relację między łaską a ludzką naturą. Każda łaska jest łaską Chrystusa, czyli łaską wcielenia i odkupienia wszystkich struktur ludzkich i kosmicznych. Dlatego też jest łaską harmonii, a nie pęknięcia pomiędzy porząadkiem naturalnym i nadprzyrodzonym, choć w Krzyżu i poprzez Krzyż. Stąd istnieje tylko jedna łaska wcielenia i odkupienia w Chrystusie. Porządek naturalny od zawsze był myślany i chciany jako wewnętrznie skierowany ku nadprzyrodzoności w Chrystusie. Podobnie porządek nadprzyrodzony był myślany i chciany jako finalizacja i pełnia porządku naturalnego w Nim. Natura i łaska pozostają odrębne, ale natura nie jest autonomiczna, lecz przyporządkowana łasce jako swej jedynej pełni. Trzeba więc zachować zarówno ich odróżnienie, jak i integrację po to, by je zharmonizować. Łaska nie jest przeciwieństwem, ale zbawieniem natury ${ }^{32}$. Świat jest więc ukierunkowany na łaskę, a przesłanie odkupienia i łaski nie jest wobec niego czymś zewnętrznym, jakby drugim, tylko zewnętrznie nałożonym piętrem, ale jego najbardziej wewnętrzną celowością ${ }^{33}$. Tezy te stanowią podstawę duchowości, która

29 Por. C. García, Espiritualidad de los laicos, Burgos 2004, s. 60n.

30 Por. R. Bultot, Théologie des réalités terrestres et spiritualité du laïcat, dz. cyt., s. 41n.

31 Por. A. Auer, Weltoffener Christ..., dz. cyt., s. 167-169.

32 Por. P. Brugnoli, La spiritualità dei laici, Brescia 1965, s. 51-61.

33 Por. J. Czarny, Ekologia, w: Leksykon duchowości katolickiej, red. M. Chmielewski, Lublin 2002, s. 243. 
odkrywa Boga w świecie, łaskę w naturze, Ducha w historii, a objawienie w doświadczeniu ${ }^{34}$.

Z powyższego wynika, że zbawienie dotyka wszystkich wymiarów ludzkiej egzystencji. Potrzeby materialne, integralnie rozumiane zdrowie, w tym również zdrowie ciała i jego naturalne potrzeby objęte działaniem Bożej łaski, wchodzą w skład holistycznie rozumianej duchowości ${ }^{35}$. Najbardziej wyrazistym przykładem takiego rozumienia duchowości jest katolicka koncepcja małżeństwa, w której pożycie małżeńskie uświęca i zbliża do Boga ${ }^{36}$.W tej koncepcji miłość małżeńska jest osobową wspólnotą, której podstawę stanowi osobowa miłość (amor). Obejmuje ona w klasycznym ujęciu wzajemne upodobanie (amor complacentiae), pragnienie wzajemnego zjednoczenia (amor concupiscentiae) i gotowość potwierdzenia wspólnoty sercem i wolą (amor benevolentiae). Jednak by ludzka miłość nie pozostała egoistycznym zaspokajaniem siebie, konieczna jest agape (caritas), jako miłość zrodzona z Boga w formie miłości Boga do człowieka i ludzkiej na nią odpowiedzi. Wymiar seksualny, erotyczny oraz amor muszą wejść w tę miłosną odpowiedź Bogu i w niej otrzymać ostateczną formę. Sfera seksualna wymaga przemiany przez erotyczną, eros przez amor, a amor przez agape. Wydaje się, że możliwie najbardziej integralne przeżywanie tej sfery wybitnie wpływa na holistycznie ujęte zdrowie człowieka w wymiarze fizycznym, psychicznym i duchowym ${ }^{37}$. Niezwykle cenne wskazówki w tym zakresie można znaleźć w encyklice Benedykta XVI Deus Caritas est ${ }^{38}$. Więź natury z łaską nabiera jeszcze innego wymiaru w chwili powstania rodziny, skoro dla teologów poczęcie i zrodzenie potomstwa stanowi obraz Trójcy Świętej. Jak Syn pochodzi od Ojca, a od nich Obu Duch, tak w starotestamentowym obrazie pierwsza kobieta pochodzi od mężczyzny i od nich wspólnie potomstwo ${ }^{39}$.

34 Por. P. Neuner, Laienspiritualität im Reformkatholizismus. Friedrich von Hügel: Frömmigkeit und Weltverantwortung, „Münchener Theologische Zeitschrift” 2 (1989), s. 122-126.

35 Por. C. García, Espiritualidad de los laicos, dz. cyt., s. 152n.

36 Por. E. Weron, Teologia życia wewnętrznego ludzi świeckich, Poznań-Warszawa 1980, s. $110-112$.

37 Por. A. Auer, Weltoffener Christ..., dz. cyt., s. 226-238.

38 Por. Benedykt XVI, enc. Deus Caritas est, 10n.

39 Por. E. Stein, Beruf des Mannes und der Frau nach Natur - und Gnadenordnung, w: Edith Stein Gesamtausgabe, 13, Freiburg im Breisgau 2002, s. 59. 
Spośród wielu wymiarów ukazujących więź natury i łaski w życiu człowieka warto jeszcze wspomnieć cierpienie, chorobę i śmierć. Już Izrael doświadczał tajemniczego związku choroby z grzechem i złem. Jezus uzdrawiał całego człowieka, najpierw odpuszczając grzechy, a dopiero później lecząc ciało (por. Łk 5, 17) ${ }^{40}$. Obraz Chrystusa Lekarza był $\mathrm{w}$ chrześcijaństwie bardzo inspirujący ${ }^{41}$. Z jednej strony należy podkreślić znaczenie postawy wobec przeżywanego cierpienia $\mathrm{w}$ duchowym dojrzewaniu osoby ${ }^{42}$. Z drugiej strony, zwłaszcza jeśli chodzi o ból fizyczny, należy podkreślać, że odwiecznym zadaniem medycyny jest wspomaganie zdrowia, ochrona życia i niesienie ulgi w cierpieniu ${ }^{43}$. W duchowości chrześcijańskiej więź natury i łaski była tu zawsze szczególnie mocna, gdyż z jednej strony generowała ona rozwój szpitalnictwa i medycyny, a nawet pojawiała się w formie duchowości sportu, z drugiej dysponowała sakramentem chorych i charyzmatyczną modlitwą uzdrowienia ${ }^{44}$.

W podobnie integralny sposób winniśmy spojrzeć na kwestię kryzysów przeżywanych przez człowieka. Analiza nauczania Jana Pawła II pokazuje, że życie duchowe w jego ujęciu jest takim działaniem Ducha Świętego i zarazem taką współpracą ze strony człowieka włączonego w Kościół, których celem jest coraz pełniejszy udział w życiu Przenajświętszej Trójcy, czyli uświęcenie, a zarazem osobowa dojrzałość. Ta współpraca z działaniem nadprzyrodzonym postulatywnie zakłada progres życia duchowego, jednak dopuszcza także zmienność, a nawet przejściowy regres. „Zmienność ludzkiej natury, a przy tym złożoność uwarunkowań,

40 Por. A. Posacki SJ, Ezoteryzm i okultyzm - formy dawne i nowe, Radom 2009, s. 362.

${ }^{41}$ Por. J. Królikowski, Chrześcijanie pierwszych wieków i medycyna. Początki działalności dobroczynnej w Kościele, w: Misericors. 75 lat działalności Caritas Diecezji Tarnowskiej, pod red. P. Grzanki, Tarnów 2012, s. 59.

42 Por. Jan Paweł II, List Salvifici doloris, 5; M. Barbero, Cierpienie, w: Słownik duchowości wincentyńskiej, t. 1, red. J. Dukała, Kraków 1997, s. 156; R. Melzack, P. D. Wall, Tajemnica bólu, przekł. E. Wesołek, Kraków 2006, s. 31.

43 Por. L. Kowalczyk, Lekarz wobec cierpienia i śmierci człowieka, w: Cierpienie i śmierć, pod red. A. J. Nowaka, Lublin 1992, s. 165 (Homo Meditans, 13).

${ }_{44}$ Por. S. Pogodzińska, Sport jako droga doskonalenia człowieka, „Wrocławski Przegląd Teologiczny" 18 (2010) nr 2, s. 125; S. Drzyżdżyk, Sakrament chorych a odpuszczenie grzechów, „Polonia Sacra” 12 (2008) 22, s. 133; A. Zwoliński, Charyzmatyczne uzdrowienie, w: A. Zwoliński, Leksykon terapii alternatywnych, Kraków 2013, s. 54-58. 
w jakich to życie duchowe się aktualizuje, sprawia, że jego przebieg ma charakter raczej sinusoidalny, nigdy zaś linearny, a tym bardziej paraboliczny” ${ }^{45}$. Niektórzy dostrzegają związek neurotycznej dezintegracji pozytywnej i twórczego przeżywania kryzysów oraz stanów nerwicowych w ujęciu Kazimierza Dąbrowskiego z nocą ciemną u św. Jana od Krzyża. W obu wypadkach bolesne doświadczenia otwierają na nowe możliwości bytowania ${ }^{46}$. Generalnie w całym życiu, również duchowym, obowiązuje prawo, które Viktor Frankl wyraził w następujący sposób: „Podstawą zdrowia psychicznego jest pewien stopień napięcia - rozdźwięk pomiędzy tym, co już osiągnęliśmy, i tym, co jeszcze mamy osiągnąć, albo tym, kim jesteśmy, a kim być powinniśmy. Tego rodzaju napięcie jest nieodłączną cechą ludzkiej natury, a co za tym idzie niezbędnym warunkiem zdrowia psychicznego" ${ }^{47}$.

Podobnie jak holistyczny rozwój człowieka, który ujmuje wzrost jako trwający całe życie wysiłek, by zintegrować różne aspekty, które stanowią jaźń, również holistyczna duchowość widzi staranie o osobową pełnię jako integralną część drogi do świętości. Holistyczne ujęcie życia duchowego zakłada, że dążenie do świętości nie jest wrogie naturalnemu ludzkiemu wzrostowi, a ludzie dążący do pobożności nie są wyjęci z ludzkich uwarunkowań i muszą wypracowywać wzrost do pełni w kontekście walki duchowej. Muszą wciąż inwestować w ciągły ludzki wzrost w dawaniu i otrzymywaniu miłości. W oparciu o przekonanie, że dojrzałość przychodzi stopniowo, holistyczna duchowość widzi ludzki wzrost jako istotny dla dojrzewania religijnego. W tym duchu można postrzegać próby, jakie Barry McLaughlin wypracowuje na polu relacji między psychospołecznymi stadiami Erika Eriksona a rozwojem religijnym. Życie duchowe niebudowane na solidnym ludzkim rozwoju zrodzonym z wewnętrznej walki może być podejrzewane o powierzchownośćc ${ }^{48}$.

45 M. Chmielewski, Duchowość według Jana Pawła II. Studium na podstawie encyklik $i$ adhortacji, Lublin 2013, s. 77.

${ }_{46}$ Por. J. Skawroń, Noc ducha i dezintegracja pozytywna, Kraków 2007, s. 395n.

${ }_{47}$ V. E. Frankl, Człowiek w poszukiwaniu sensu, przekł. A. Wolnicka, Warszawa 2009, s. 158 n.

48 Por. W. Au, Holistic Spirituality, dz. cyt., s. 489. 


\section{Sacrum i profanum}

Jeszcze inny dualizm, trudny do pogodzenia z holistycznym ujęciem duchowości, stanowi zbyt radykalny podział na to, co należy do sfery sacrum, i to, co należy do sfery profanum. Takie podejście ogranicza wymiar duchowości do pewnych czasów, miejsc i doświadczeń wyraźnie związanych z religią i kultem. Zwyczajne doświadczenia dnia traktuje się wtedy, jakby były pozbawione obecności Bożej, czyli bez znaczenia we wzroście duchowym. Holistyczna duchowość podkreśla, że żyjemy w Bożym środowisku i każde stworzenie potencjalnie objawia Stwórcę ${ }^{49}$. Już Teilhard de Chardin uważał, że na mocy stworzenia i jeszcze bardziej wcielenia nic na ziemi nie jest profanum dla tego, kto umie patrzeć. Przeciwnie, wszystko jest sacrum dla człowieka, który dostrzega we wszelkim stworzeniu cząstkę bytu wybranego i poddanego przyciąganiu Chrystusa na drodze do spełnienia ${ }^{50}$. Później zwłaszcza Karl Rahner rozwinął ,teologię spraw codziennych", teologię pracy, rozrywki i podstawowych czynności, ukazującą, jak w głębi codziennej, monotonnej egzystencji możliwe jest intensywne doświadczenie Boga. W jego oczach nie ma niczego z profanum w głębi zwyczajnego życia. Na tej podstawie opracował prawdziwą mistykę codzienności, która spotyka Boga we wszystkim ${ }^{51}$. Takie ujęcie przenikania profanum przez sacrum ma wpływ również na rozumienie związku doczesności z wiecznością. Zadaniem Kościoła jest przekształcanie świata w królestwo Boże $\mathrm{e}^{52}$. Ale to królestwo nie jest czymś jedynie przyszłym. Rzeczywistości eschatologiczne nie są jedynie spełnieniem, które pojawi się na końcu czasów, ale już w każdej epoce Kościoła nadają teraźniejszości jej wewnętrzny sens. W pewnym sensie rzeczywistości ostateczne są już obecne i aktywne pomiędzy nami ${ }^{53}$.

Takie rozumienie relacji sacrum i profanum chroni przed niebezpieczeństwem pewnego redukcjonistycznego monizmu, który znosi

9 Por. W. Au, Holistic Spirituality, dz. cyt., s. 489n.

50 Por. P. T. de Chardin, Le milieu divin, Paris 1957, s. 56.

51 Por. H. Egan, I mistici e la mistica. Antologia della mistica cristiana, Città del Vaticano 1995, s. $667,669$.

52 Por. P. Brugnoli, La spiritualità dei laici, dz. cyt., s. 103-105.

53 Por. Y. M.-J. Congar, Jalons pour une théologie du laïcat, dz. cyt., s. 96. 
napięcie między Kościołem a światem na rzecz Kościoła, oceniając całą rzeczywistość według kryterium sakralności ${ }^{54}$. Unika się w ten sposób sakralizmu, który dzieli całą aktywność człowieka na sferę sacrum, do której zalicza się modlitwę i życie sakramentalne, oraz profanum, obejmującą resztę przeżywanego czasu. Nie jest prawdziwą alternatywą odmiana tej formy duchowości w postaci hierarchizmu. W tym wypadku tworzy się pewną hierarchiczną „drabinę” ważności działań z punktu widzenia uświęcenia. To ujęcie dostrzega wprawdzie wartość wszystkich innych działań, które nie skupiają się bezpośrednio na relacji z Bogiem, ale zasadniczo przyjmuje ich niższą wartość i mniejsze znaczenie. Bardziej wymagający i odpowiedni dla duchowości holistycznej wydaje się finalizm, który wymaga tylu i takich ćwiczeń duchowych, ile i jakie są konieczne do stałego wzrostu duchowego. Poza tym finalizm pozwala zdecydować, co bardziej odpowiada Bożej woli w danym momencie życia i lepiej prowadzi ku świętości ${ }^{55}$.

Takie ujęcie duchowości ma istotne znaczenia dla holistycznie rozumianego zdrowia człowieka, gdyż pozwala dostrzec prawdziwą wartość takich doczesnych rzeczywistości jak praca i odpoczynek. Eutrapelia, jako cnota godziwego wypoczynku i zabawy, pozwala wyzwolić się z zabiegania i gorączkowości współczesnej pracy i odpoczynku mierzonych bardziej miarą ilości niż jakości ${ }^{56}$. Holistyczna duchowość pracy wskazuje, że wysiłek człowieka może osiągnąć pełnię wartości naturalnych i nadprzyrodzonych tylko w doskonałej jedności wewnętrznej intencji i zewnętrznego dzieła. Tu wewnętrzna, dobra intencja winna się łączyć z solidnym wykonaniem, a wiara, nadzieja i miłość mają się wcielić w dobrą pracę, spełnianą zgodnie z własnymi zdolnościami moralnymi i technicznymi ${ }^{57}$. Współczesne optymistyczne ujęcie pracy podkreśla partnerstwo człowieka wobec Boga Stwórcy, autonomiczną wartość pracy i jej nadrzędność wobec wszystkich innych elementów życia ekonomiczno-gospodarczego oraz uczestnictwo w królewskiej władzy Chrystusa

54 Por. A. Auer, Weltoffener Christ..., dz. cyt., s. 99-104.

55 Por. W. Zyzak, Co mam czynić, aby osiagnać życie wieczne? Duchowość chrześcijańska na świeckiej drodze życia, Kraków 2008, s. 398.

56 Por. J. W. Gałkowski, Czas wolny, w: Katolicyzm A-Z, red. Z. Pawlak, Poznań 1989, s. 61.

57 Por. P. Brugnoli, La spiritualità dei laici, dz. cyt., s. 156-164. 
przez doskonalenie świata i człowieka jako czynnik w kosmogenezie i antropogenezie ${ }^{58}$. Najważniejsze jednak jest dostrzeżenie miłości jako cnoty obejmującej całość egzystencji człowieka, co pozwala człowiekowi, by jego praca stawała się wyrazem kultu Boga, czyli prawdziwe uświęcającą modlitwą ${ }^{59}$. Nie można jednocześnie zapomnieć, że rozwój techniczny i związana z nim ewolucja pracy ma podwójne oblicze, gdyż oznacza wzrost poznania praw natury, ale też wyobcowanie człowieka z natury; wzrost racjonalizacji, ale też zmniejszenie duchowej inicjatywy; opanowanie natury w wielkich przedsiębiorstwach, ale też nowe formy ludzkiej niesamodzielności i utraty godności; olbrzymie możliwości kształcenia technicznego, ale też ujednolicenie myślenia i czucia; postęp medycyny, ale też powstanie nowych chorób, zwłaszcza zawodowych; zbliżenie ludzi w skupiskach, a z drugiej strony nowe formy osamotnienia ${ }^{60}$.

Więź sacrum i profanum ma jeszcze jeden aspekt mocno akcentowany we współczesnej duchowości holistycznej. Tradycyjna duchowość obwiniana jest za brak równowagi, gdyż akcentując przesadnie perspektywę eschatologiczną, zajęta królestwem, które ma nadejść, zaniedbywała w rezultacie królestwo Boże już inaugurowane przez głoszenie i posługę Jezusa. Świat deprecjonowany jako jedynie tymczasowa dolina łez nie motywuje do zaangażowania, a polityczne czy ekonomiczne sprawy wydają się w tej perspektywie bez związku z duchowością. Tymczasem holistyczna duchowość stwierdza, że bycie uczniem wymaga kontynuacji dzieła Jezusa na rzecz sprawiedliwości i pomocy ubogim, w ekologicznej odpowiedzialności ${ }^{61}$. Współcześnie obserwuje się wzrost zagrożenia naturalnego środowiska człowieka, spowodowany przez brak ekologicznego myślenia w gospodarce i przemyśle. Powoduje to bezpośrednie zagrożenie biologicznej egzystencji człowieka, a także jego degradację moralną ${ }^{62}$. Duchowość ekologiczna, której głównym propagatorem jest papież Franciszek i jego encyklika Laudato si’ z 25 maja 2015 roku, poświę-

58 Por. J. W. Gałkowski, Praca, w: Katolicyzm A-Z, dz. cyt., s. 322.

59 Por. G. Thils, Les laïcs et l'enjeu des temps „post-modernes”, „Cahiers de la Revue Théologique de Louvain" 20, Louvain-la-Neuve 1988, s. 105-109.

60 Por. A. Auer, Weltoffener Christ..., dz. cyt., s. 178-194.

61 Por. W. Au, Holistic Spirituality..., dz. cyt., s. 490.

62 Por. J. Czarny, Ekologia, dz. cyt., s. 243. 
cona „trosce o wspólny dom”, zachęca do nawrócenia, które wiąże się z rozwijaniem wszystkich konsekwencji spotkania z Jezusem w relacjach z otaczającym światem. Zdaniem Franciszka nie jest to jakiś drugorzędny element doświadczenia chrześcijańskiego (nr 217). Powyższe uwagi pokazują, że na wymiar sacrum i profanum należy patrzeć nie jako na wymiary wrogie czy konkurencyjne, ale przenikające się i komplementarne.

\section{Więź wymiaru indywidualnego i społecznego}

Duchowość holistyczna przyjmuje, że miłość Boga i bliźniego są nieoddzielne, i dlatego wymaga zerwania z jedynie indywidualistyczną, prywatną mentalnością ,ja-Jezus”, która nie uwzględnia miłości do bliźnich ${ }^{63}$. Taka duchowość bazuje na koncepcji Kościoła jako komunii, co pozwala uniknąć ryzyka zarówno skrajnego indywidualizmu, jak i bezosobowego kolektywizmu. Dla zdrowego rozwoju duchowego człowieka potrzebna jest świadomość własnej odpowiedzialności i poczucie przynależenia do wspólnoty ${ }^{64}$. Taki model duchowości uwzględnia indywidualną relację do Boga, która realizuje się zasadniczo w ramach wspólnoty parafialnej. Nie do przecenienia w tym zakresie są także powstające głównie po soborze watykańskim II ruchy, skupiające wiernych i pozwalające na rozwijanie indywidualnych charyzmatów ${ }^{65}$. Również w ostatnim okresie została mocniej zaakcentowana, głównie w ramach przygotowania do kapłaństwa, potrzeba formacji ludzkiej, która obok formacji duchowej winna pomóc w nabyciu dojrzałości osobowej, koniecznej do odpowiedniego spełniania posługi w złożonym kulturowo środowisku. W ten sposób również sama formacja duchowa zaczęła być coraz bardziej „szukaniem Chrystusa w ludziach”, gdyż spotkanie z Bogiem domaga się spotkania z bliźnimi w postawie bezinteresownej służby ${ }^{66}$.

63 Por. W. Au, Holistic Spirituality..., dz. cyt., s. 490.

${ }^{64}$ Por. C. García, Espiritualidad de los laicos, dz. cyt., s. 138n.

65 Por. H. U. von Balthazar, Gottbereites Leben. Der Laie und der Rätestand. Nachfolge Christi in der heutigen Welt, Freiburg 1993, s. 219-221.

${ }_{66}$ M. Chmielewski, Duchowość według Jana Pawła II..., dz. cyt., s. 118n. 
Takie wejście wymiaru wertykalnego w wymiar horyzontalny w ramach duchowości holistycznej winno owocować nie tylko w życiu i działalności wspólnoty Kościoła, ale także na wszystkich innych polach zaangażowania chrześcijańskiego. Tak również należy rozumieć politykę, która jest troską o dobro wspólne. Dlatego udział w niej jest prawem i obowiązkiem wszystkich. Chrześcijanie są odpowiedzialni za przenikanie życia politycznego duchem Ewangelii i winni traktować udział w polityce jako służbę ${ }^{67}$.

Uprzywilejowanym miejscem realizacji nowego rozumienia duchowości holistycznej otwierającej horyzonty wspólnotowe jest tak klasyczny temat jak asceza. Starsza asceza widziała życie chrześcijańskie bardziej w aspekcie osobistej formacji niż służby czy apostolatu. Najpierw następuje przemiana duchowa, później służba jest jej wyrazem. Centrum życia chrześcijańskiego stanowi modlitwa, czyli rozmowa z Bogiem. Ta koncepcja uwypukla pozaświatowe, transcendentne aspekty misterium Chrystusa, koncentrując się bardziej na indywidualnej relacji do Boga niż na relacji do bliźniego i świata. Mało uwzględnia odpowiedzialność za budowę nowego nieba i nowej ziemi. Królestwo Boże jest królestwem dusz, które należy wyratować, a wszystko inne jest relatywne. Ludzkie sprawy i doczesne rzeczy nie mają tu trwałego znaczenia, gdyż są tylko środkami, których wartość zależy od użyteczności dla ratowania duszy. $\mathrm{Na}$ świat patrzy się jak na zagrożenie i pułapkę, z której należy uciec. Raczej należy się trzymać z dala od ziemskich spraw, by nie zejść na fałszywą drogę. Umartwienie ma zneutralizować wpływy ciała i w tym celu odmawia się zmysłom ich specyficznych obiektów, by umożliwić poszukiwanie kontemplacyjnego zjednoczenia z Bogiem. Cisza i samotność zaradzają rozproszeniom świata. Nieuporządkowana miłość własna jest radykalnie zwalczana, zwłaszcza przez wybór tego, co trudniejsze i mniej pociągające. Duchowe życie stanowi walkę miedzy biegunami miłości Bożej i nieuporząadkowanej miłości własnejej ${ }^{68}$.

67 Por. T. Reroń, Polityka, w: Leksykon duchowości katolickiej, dz. cyt., s. 654.

68 Por. E. Larkin, Die Askese im modernen Leben, „Internationale Zeitschrift für Theologie Concilium" 1966, s. 703-705. 
W nowej ascezie zamiast szukać Boga poza światem w czystej adoracji, chrześcijanin zaczyna od siebie i od świata, oczekując, że znajdzie tam Boga. Ponieważ Zmartwychwstały żyje we wspólnocie wiernych, chrześcijanin wzrasta przez apostolską działalność. W duchowości inkarnacyjnej zepsuty świat jest jednocześnie odkupiony i znajduje się na drodze do ostatecznego wyzwolenia. Dlatego mniejszą wagę przykłada się do grzechu w świecie niż do łaski dla świata. Grzech pozostaje przeszkodą, ale zostaje równie dobrze wyłączony przez dzieła pozytywnej miłości, jak wcześniej przez frontalny atak. Główną linią duchowego wysiłku nie jest już walka z nieuporządkowaną miłością, ale zaangażowanie i działanie dla innych. Taka asceza sięga optymistycznie po ludzkie motywacje i identyfikuje swoje plany z dziełem Pana. Chrześcijanin, biorąc na siebie trudności, wznosząc się ponad egoistyczne impulsy, rozczarowania i niewdzięczność, znajduje wiele okazji do wyrzeczenia się siebie, do cierpienia i umartwienia. Dlatego nakładane samemu umartwienia zdają się mu sztucznymi ludzkimi wymysłami w porównaniu z krzyżem, który w sposób nieunikniony niesie ze sobą ludzka kondycja. Ten wysiłek jest prawdziwą realizacją tajemnicy Wielkanocy, będąc inkarnacją prawdziwej miłości. Tu jest różnica akcentu wobec dawnej ascezy, która „starała się trzymać wroga przed murami”. Nowa jest bardziej ofensywna, starając się patrzeć poza mury własnego ,ja”. Postawa introspekcji wydaje jej się podejrzana, dlatego szuka drogi do Boga przez ekstrawersję i akcję. Jednak ta forma skłonna jest do zaniedbywania kontemplacji. Będąc bardziej na linii apostolskiego zaangażowania dla zbawienia świata niż na linii zjednoczenia kontemplacyjnego, musi jednak pamiętać, że oba dążenia wzajemnie od siebie zależą. W tej koncepcji chrześcijanin pragnie znajdować Boga tam, gdzie On chce do nas przyjść, w spotykanych ludziach, w pracy i w społeczeństwie. To wyklucza niezdrową, emocjonalnie zabarwioną ucieczkę od świata pod przykrywką duchowego życia. Chęć miłowania jedynie Boga może być bowiem zasłoną braku miłości do świata, formą alibi dla egoistycznego braku zainteresowania innymi ludźmi czy dla niechęci przyjęcia ludzkich zadań. Wtedy jest to fałszywa duchowość. Oczywiście również nowa koncepcja ascezy nie eliminuje tradycyjnych elementów, takich jak post. Zwłaszcza dziś, gdy powszechne wydaje się podejmowanie różnego rodzaju diet z powodów 
zdrowotnych czy estetycznych, warto, by również duchowość miała swój wkład w holistycznie ujęte dobro człowieka ${ }^{69}$.

Podsumowując krótko nasze rozważania na temat ascezy, przypomnijmy, że w nowej koncepcji trzeba czynnie wchodzić w otaczający świat przez pozytywne dzieło miłości do wszystkich i wszystkiego. Ideą przewodnią nie jest oczyszczenie, lecz zaangażowanie się, które obejmuje codzienne postępowanie, pracę, czas wolny, rozrywkę i oddanie siebie bliźnim. Spokojne i cierpliwe przyjmowanie trudności życia dostarcza okazji do cierpienia i wyrzeczenia. Nowa asceza jest ofensywna i szeroko otwarta na otaczającą rzeczywistość. Szuka Boga tam, gdzie On przychodzi: pomiędzy ludźmi, których spotyka się podczas pracy, w czasie rozrywki czy w podróży ${ }^{70}$. Tak rozumiana asceza obejmuje wszystkie poziomy życia duchowego: somatyczny, psychiczny, społeczny i religijny ${ }^{71}$.

\section{Zakończenie}

Wypełnianie życia chrześcijańskiego w sposób zrównoważony, by nie przeakcentować żadnego aspektu ze szkodą dla innych, to zadanie duchowości holistycznej. Pragnie ona uzdolnić ludzi do tworzenia bardziej żywotnej więzi wiary i życia codziennego, przezwyciężając dychotomię tego, co naturalne, i tego, co nadprzyrodzone, sakralne i świeckie, duchowe i cielesne, intelektualne i emocjonalne, indywidualne i wspólnotowe. Duchowość holistyczna uznaje, że wszystkie aspekty życia osoby muszą podlegać przemieniającemu wpływowi Ducha. Chce ująć totalność egzystencji osoby, czyli nie tylko relację z Bogiem, ale także z bliźnimi, z własnym dziełem i ze światem materialnym, uznając wszelkie ludzkie troski za ważne. Ducha Boga można spotkać w każdym aspekcie życia, a nie tylko w aktach religijnych modlitwy i liturgii. Rozumienie duchowości holistycznie zakłada połączenie jej z każdym aspektem ludzkiego rozwoju: psychologicznym i duchowym, międzyosobowym

\footnotetext{
69 Por. E. Larkin, Die Askese im modernen Leben, dz. cyt., s. 705-707.

70 Por. A. Żynel, Asceza, w: Katolicyzm A-Z, dz. cyt., s. 20.

71 Por. K. Waaijman, Handbuch der Spiritualität, t. 2, Mainz 2005, s. 47.
} 
i politycznym. Ujmując duchowość jako szczególny sposób bycia w świecie, drogi do przejścia w odróżnieniu od jedynie drogi w umyśle, holistyczna duchowość zajmuje się pomocą ludziom, by wcielić w życie wartości, które wyznają. Koncept struktury życia zakłada specyficzne wybory i decyzje ludzi odnośnie do tego, jak wydają pieniądze, spędzają czas i wykorzystują posiadane środki. Ważne jest tu odpowiednie ujęcie pracy, odpoczynku, modlitwy, polityki i relacji międzyludzkich. Tak rozumiana duchowość może pomóc ludziom połączyć różne aspekty ich życia w sposób koherentny i odpowiedzialny ${ }^{72}$.

72 Por. W. Au, Holistic Spirituality, dz. cyt., s. 490. 


\section{Summary}

\section{Holistyczny charakter duchowości chrześcijańskiej}

Autor artykułu omawia wpływ duchowości na zdrowie człowieka w ujęciu holistycznym. W tym celu rozwija holistyczne pojęcie duchowości, które bazuje na integralnej antropologii, ujmującej człowieka jako jedność duchowo-cielesną. Tekst podkreśla związek natury i łaski, wymiaru profanum i sacrum, a także indywiduum i wspólnoty.

Słowa kluczowe: duchowość holistyczna, sacrum i profanum, natura i łaska

\section{Holistic Character of Christian spirituality}

The author of the article discusses the impact of spirituality on the human health from a holistic point of view. For this purpose he introduces the holistic idea of spirituality, which is based on integral anthropology, understanding a human being as spiritual-corporal unity. The text underlines the connection between nature and grace, sacred and profane, individual and community.

Keywords: holistic spirituality, sacred and profane, nature and grace

\section{Bibliografia}

Au W., Holistic Spirituality, w: The New Dictionary of Catholic Spirituality, ed. M. Downey, Collegeville 1993, s. 488-491.

Auer A., Weltoffener Christ. Grundsätzliches und Geschichtliches zur Laienfrömmigkeit, Düsseldorf 1966.

Barbero M., Cierpienie, w: Słownik duchowości wincentyńskiej, t. 1, red. J. Dukała, Kraków 1997, s. 156.

Beer F., Kobiety i doświadczenie mistyczne w średniowieczu, przekł. A. Branny, Kraków 1996.

Benedykt XVI, Encyklika Deus Caritas est.

Brugnoli P., La spiritualità dei laici, Brescia 1965.

Chmielewski M., Ciało i duchowość. Zarys problematyki, „Ethos” 4 (2008), s. 47-57.

Chmielewski M., Duchowość według Jana Pawła II. Studium na podstawie encykliki adhortacji, Lublin 2013.

Congar Y. M.-J., Jalons pour une théologie du laïcat, Paris 1954.

Congar Y., Laïc et Laïcat, w: Dictionnaire de spiritualité, t. 9, Paris 1976, k. 79-108.

Czarny J., Ekologia, w: Leksykon duchowości katolickiej, red. M. Chmielewski, Lublin 2002, s. 243. 
De Chardin P. T., Le milieu divin, Paris 1957.

Drzyżdżyk S., Sakrament chorych a odpuszczenie grzechów, „Polonia Sacra” 12 (2008) 22, s. 127-139.

Egan H., I mistici e la mistica. Antologia della mistica cristiana, Città del Vaticano 1995. Frankl V. E., Człowiek w poszukiwaniu sensu, przekł. A. Wolnicka, Warszawa 2009.

Gallo L., Spiritualità dei movimenti di liberazione, w: Movimentiecclesiali contemporanei, a cura di A. Favele, Roma 1980, s. 445-465.

García C., Espiritualidad de los laicos, Burgos 2004.

Gogola J. W., Zjawiska towarzyszace mistyce: ekstaza i stygmaty, w: Stygmaty i stygmatycy, red. Z. Kijas, Kraków 2005, s. 45-60.

Häring B., Nauka Chrystusa, t. 3, Poznań 1963.

Jan Paweł II, List Salvifici doloris.

Jędrzejewski S., Pochodzenie człowieka w apokaliptyce międzytestamentalnej, „Polonia Sacra" 2 (1988) 46, s. 117-127.

Juzba K., La compassione di Francesco d'Assisi per gli altri e per il Creato, „Polonia Sacra” 18 (2014) 1, s. 93-132.

Kowalczyk L., Lekarz wobec cierpienia i śmierci człowieka, w: Cierpienie i śmierć, pod red. A. J. Nowaka, Lublin 1992, s. 163-169 (Homo Meditans, 13).

Larkin E., Die Askese im modernen Leben, „Internationale Zeitschrift für Theologie Concilium" 1966, s. 703-707.

Melzack R., Wall P. D., Tajemnica bólu, przekł. E. Wesołek, Kraków 2006.

Moioli G., Mistica cristiana, w: Nuovo Dizionario di Spiritualitá, a cura di S. De Fiores, T. Goffi, Roma 1979, s. 988.

Mrzygłód P., Dusza i ciało jako integralne składowe ludzkiego bytu. Stanowisko metafizyki realistycznej, „Wrocławski Przegląd Teologiczny” 20 (2012) nr 1, s. 177-196.

Nowak A. J., Ślub czystości czy konsekracja ciała?, w: Ku szczęściu - bez oszustwa, pod red. J. Misiurka, A. J. Nowaka, W. Słomki, Lublin 1997, s. 151-165 (Homo Meditans, 18).

Orzeszyna J., Zagrożenia antropologicznych podstaw rodziny na kanwie wypowiedzi Jana Pawta II, „Polonia Sacra” 12 (2008) 23, s. 97-114.

Piasecki P., Medytacja chrześcijańska. Antropologiczno-teologiczne podstawy w perspektywie duchowości azjatyckiej, Poznań 2008.

Pogodzińska S., Sport jako droga doskonalenia człowieka, „Wrocławski Przegląd Teologiczny" 18 (2010) nr 2, s. 113-136.

Posacki A., Ezoteryzm i okultyzm - formy dawne i nowe, Radom 2009.

Ross S. A., Body, w: The New Dictionary of Catholic Spirituality, ed. M. Downey, Collegeville 1993, s. 93-100.

Schulte R., Leib und Seele. III. Systematisch-theologisch, w: Lexikon für Theologie und Kirche, t. 6, Freiburg im Breisgau 2006, k. 775n.

Skawroń J., Noc ducha i dezintegracja pozytywna, Kraków 2007.

Stein E., Der Aufbau der menschlichen Person. Vorlesung zur philosophischen Anthropologie, Freiburg im Breisgau 2004.

Von Balthazar H. U., Gottbereites Leben. Der Laie und der Rätestand. Nachfolge Christi in der heutigen Welt, Freiburg 1993. 
Waaijman K., Handbuch der Spiritualität, t. 1, Mainz 2004.

Waaijman K., Handbuch der Spiritualität, t. 2, Mainz 2005.

Weron E., Teologia życia wewnętrznego ludzi świeckich, Poznań-Warszawa 1980.

Winling R., Teologia współczesna, przeł. K. Kisielewska-Sławińska, Kraków 1990.

Wrona-Polańska H., Twórcze zmaganie się ze stresem szansą na zdrowie, Kraków 2011.

Zarzycki S. T., Ku zrozumieniu istoty serca, w: Najważniejsza jest miłość, red. M. Chmielewski, Lublin 1999, s. 131-142.

Zwoliński A., Charyzmatyczne uzdrowienie, w: A. Zwoliński, Leksykon terapii alternatywnych, Kraków 2013, s. 54-58.

Zyzak W., Co mam czynić, aby osiagnać życie wieczne? Duchowość chrześcijańska na świeckiej drodze życia, Kraków 2008. 